\title{
The development of photorefractoriness in termination of the breeding season in the tropical brahminy myna: role of photoperiod
}

\author{
V Kumar *, BS Kumar
}

Department of Zoology, Meerut University, Meerut-250004, India

(Received 3 March 1990; accepted 11 October 1990)

\begin{abstract}
Summary - Gonads of brahminy myna (Sturnus pagodarum) spontaneously regress in July/ August when the daylength is still stimulatory. Experiments were conducted to investigate if photoperiod was involved in the timing of gonadal regression and if photorefractoriness terminated the breeding season in this species. The observations obtained in the present study clearly show that: i) increasing photoperiods of spring/summer programmed for eventual gonadal regression in the late summer; ii) the birds developed photorefractoriness to all stimulatory daylengths and consequently the breeding season could not be extended by providing more stimulatory photoperiods; and iii) exposure to short daylength treatment failed to overcome the onset of refractoriness in birds after they had attained full gonadal growth and development. These results suggest that refractoriness is a process used by the brahminy myna to terminate the breeding season, and that this species becomes totally photorefractory.
\end{abstract}

photorefractoriness / breeding / photoperiod / bird / myna

Résumé - Développement d'un état photoréfractaire à la fin de la saison de reproduction chez le mainate brahmane tropical : rôle de la photopériode. Les gonades de mainate brahmane (Sturnus pagodarum) régressent spontanément en juillet-août, alors que la durée du jour est encore de nature stimulante. Des expériences ont été conduites pour rechercher si la photopériode intervient dans la programmation de la régression des gonades et si un état photoréfractaire met fin à la saison de reproduction dans cette espéce d'oiseaux. Les résultats de ces travaux montrent que :

- des photopériodes croissantes données au printemps et en été programment une éventuelle régression gonadique en fin d'été,

- un état réfractaire se met en place quelle que soit la durée quotidienne de la photopériode stimulante et la saison de reproduction ne peut donc pas être prolongée en poursuivant le régime photostimulant et

- les traitements de cjours courts" ne peuvent pas empêcher l'établissement de la phase photoréfractaire lorsqu'ils sont donnés après que les gonades des oiseaux ont atteint leur plein développement. Ces résultats suggèrent que l'état réfractaire est un moyen utilisé par le mainate brahmane pour mettre fin à la saison de reproduction au cours de l'année et que cette espèce devient totalement photoréfractaire.

reproduction / photopériode / état réfractaire / oiseau / mainate

\footnotetext{
* Correspondence and reprints.
} 


\section{INTRODUCTION}

In seasonally breeding animals, the breeding season is restricted to the optimum period for raising young, which varies widely to suit the ecological needs of each species. In most species of birds from temperate latitudes, in which reproduction usually begins some time during spring, the breeding season ends by the development of a state of refractoriness which results in spontaneous gonadal collapse and loss of response to stimulatory daylengths; once the birds are photorefractory, exposure for a time to short daylengths is necessary to render them photosensitive again (Murton and Westwood, 1977; Farner et al, 1983; Follett, 1984; Stokkan and Sharp, 1984; Nicholls et al, 1988). Similar results have been found in some spring/summer breeders that reproduce at high latitudes but overwinter in the tropics (Tewary and Kumar, 1982; Kumar and Tewary, 1983; Tewary and Tripathi, 1983).

In the tropics, breeding seasons among birds are spread out over the entire year and correspond to existent favourable conditions, but reproduction in individual species is essentially seasonal (for review see Chandola et al, 1983). A number of species breed during spring and summer, and some of them react to photoperiods similar to those of temperate species (Thapliyal and Tewary, 1964; Epple et al, 1972; Lewis et al, 1974; Thapliyal, 1981; Dittami and Gwinner, 1985; Gwinner and Dittami, 1984; Tewary and Tripathi, 1985; Tewary and Dixit, 1986). However, the mechanisms controlling the termination of the breeding season in these photosensitive species are divergent and remain controversial. While photorefractoriness is lacking in some long-day breeders (Thapliyal and Saxena, 1964; Miller, 1965; Epple et al, 1972; Lewis et al, 1974), a few birds are reported to undergo spontaneous gon- adal regression under continuous long day-lengths (Lofts, 1962; Thapliyal, 1981; Tewary and Tripathi, 1985; Tewary and Dixit, 1986).

Therefore we sought to study the importance of refractoriness in the reproductive cycle of a subtropical spring/summer breeder, the brahminy myna (Sturnus pagodarum), which is a widely distributed resident species in India. It has a distinct annual gonadal cycle with breeding periods varying according to the locality, between March and August (Ali and Ripley, 1972). At Meerut, India (latitude $29^{\circ} 1 \mathrm{~N}$; longitude $77.45^{\prime} \mathrm{E}$ ), the gonads begin to recrudesce in March/April when daylengths increase $(\approx 12-13 \mathrm{~h})$, and reproduction ends in July/August when daylengths decrease $(\approx 13.7-13 \mathrm{~h}$ ) but are still longer than the inductive photoperiods. Under laboratory conditions long daily photoperiods (14-16 h) induce a gonadal growthinvolution cycle within 3-4 months, but not during sexually quiescent periods (Kumar, 1988; unpublished observations). This indicates that in brahminy myna the end of the breeding season is marked by spontaneous gonadal regression as well as by failure to respond to further photoperiodic stimulation, similar to temperate species, including European starlings of the same genus (for refractoriness in starlings, see in particular Dawson and Goldsmith, 1983; Dawson et al, 1985; Dawson, 1987; Nicholls et al, 1987).

The present experiments were designed to determine whether refractoriness was a process used by the brahminy myna to terminate its breeding season. We also investigated whether: i), the breeding season could be extended by exposure to stimulatory photoperiods before the onset of gonadal regression; and ii) responsiveness to long photoperiods could be maintained by the short-day treatment when the birds had attained full gonadal maturation. 


\section{MATERIALS AND METHODS}

In the present study, we used wild birds caught and kept in an outdoor aviary at Meerut. At Meerut $\left(29^{\circ} \mathrm{N}\right)$, seasonal variations in official daylength (measured from the onset of official dawn to the end of official dusk) occur between the shortest daylength of $11 \mathrm{~h} 05 \mathrm{~min}$ (22nd December) and the longest daylength of $14 \mathrm{~h} 57 \mathrm{~min}$ (23 June); this includes 24-28 min of morning and evening official twilight periods. The birds were acclimatized to indoor laboratory conditions for $15 \mathrm{~d}$ before experimentation. During artificial photostimulation in the different photoperiods of series I-III, the birds were held in lightproof chambers lit by fluorescent tubes at an intensity of $\approx \mathbf{3 0 0}$ lux.

All birds were provided food and water ad libitum. Periodic observations of the gonads were made by laparotomy. In males, the dimensions of the left testis and in females, the diameter of the largest ovarian follicle were recorded. Testicular volume was calculated from $4 / 3 \pi a^{2}$ where $a$ and $b$ denoted half the long and short axes, respectively. In females, an unstimulated ovarian follicle was rated as $0.3 \mathrm{~mm}$ in diameter to make the observations statistically comparable. In this study, we chose the testicular volume (TV) in males and the diameter of the largest ovarian follicle (FD) in females as indexes of the photoperiodic effects on reproductive activity since increase in the size of the gonads over a period of time, as a function of photoperiodic stimulation, reflects the summation of the gametogenetic changes involving at least $\mathrm{LH}, \mathrm{FSH}$ and androgens (Lofts and Murton, 1973; Lofts $\theta t$ al, 1973; Lofts, 1975). Further, ovarian follicles develop in 2 phases (an initial slow growth phase followed by a phase of rapid or exponential growth) and so the measurement of the largest follicle indicated the response of the ovarian follicle of the prospective clutch which was ready to mature (Farner and Lewis, 1971).

\section{Experimental design}

\section{Series I}

This series determined the relationship between the onset of photorefractoriness and daylength. Two experiments were performed. In experi- ment I, which began on 4 May, 1989, a group $(n=6)$ of male and female birds were placed in continuous light (LL, 24 L:O D), long photoperiods (LDL, 16 L:8 D) and normal daylengths (NDL) for $120 \mathrm{~d}$ : the latter served as controls. Monthly observations on TV and FD were carried out.

Experiment II commenced on 6 August 1989 when gonadal regression had begun (fig 2). It thus differed from the above experiment regarding reproductive status of the birds. We examined simultaneous changes at 10-d intervals in the gonads of groups ( $n=6$ each) of male birds, held in NDL and LDL for $30 \mathrm{~d}$ to ensure the effect of LDL on the onset and progress of gonadal regression.

\section{Series II}

This experiment, begun on 23 July 1989, determined whether the development of photorefractoriness and/or spontaneous gonadal regression in NDL birds could be delayed or deferred by shifting to the artificial photoperiods. At this time, the birds in nature were experiencing a daylength of $\approx 13.7 \mathrm{~h}$ (measured from sunrise to sunset and excluding twilight periods). Four groups, each consisting of 6 males and 6 females, were studied for $60 \mathrm{~d}$. In group 1 $(12 \mathrm{~L} \rightarrow \mathrm{LL})$, birds first experienced $12 \mathrm{~L} / 12 \mathrm{D}$ for $30 \mathrm{~d}$ and then $\mathrm{LL}$ for an equal period to determine if the shift to a lower photoperiod $(12 \mathrm{~L}$ 12 D) at that time would postpone eventual development of photorefractoriness. The birds in groups 2 and 3 (14 $L$ or $16 L \rightarrow L L$ ) were exposed to $14 \mathrm{~L} / 10 \mathrm{D}$ or $16 \mathrm{~L} / 8 \mathrm{D}$ on $d 0-30$, respectively, and then to $L L$ on $d 31-60$; this procedure determined whether an additional increase in daylength would prolong the breeding season and prevent the onset of refractoriness. Group 4 was continuously maintained in $L L$ to confirm the development of photorefractoriness in the brahminy myna. The change in gonad size measured at 30-d intervals was considered as an index of the development of refractoriness in the present study.

\section{Series III}

These experiments were carried out to determine whether exposure to short daylengths (8 L/16 D) for 9 wk (a period of exposure which 
otherwise enabled regressed brahminy myna to regain photosensitivity at a time when the birds had attained full growth and gonad development) could prevent the development of photorefractoriness. In other words, would a shortday treatment enable reproductively mature birds to remain responsive to stimulatory photoperiods. On 20 May 1989,4 groups $(n=6)$ of male and 3 groups $(n=6)$ of female birds were transferred to $8 \mathrm{~L}: 16 \mathrm{D}$ for $63 \mathrm{~d}$ and examined at monthly intervals; at that time they had fully developed gonads (TV $=\approx 240.00 \mathrm{~mm}^{3} ; \mathrm{FD}=\approx$ $1.50 \mathrm{~mm}$ ). At the end of short-day exposure all the birds had fully regressed gonads (average $\mathrm{TV}=0.49-0.80 \mathrm{~mm}^{3}$; average $\mathrm{FD}=0.35 \mathrm{~mm}$ ). Subsequently, the males were transferred to 12 $L, 14 \mathrm{~L}, 16 \mathrm{~L}$ and $\mathrm{LL}$ and males the females to $12 \mathrm{~L}, 16 \mathrm{~L}$ and $\mathrm{LL}$ for a total duration of $90 \mathrm{~d}$. However, after $60 \mathrm{~d}$ the birds in $12 \mathrm{~L}$ and $14 \mathrm{~L}$ were shifted to $L L$ to determine photosensitivity. A control group ( $n=6)$ was kept on NDL to demonstrate the rate of natural gonadal regression during the time of year covered by the experiment.

A few birds (one bird in each series II group, and 2 birds in series III) died during the course of investigation, and their data were excluded from the statistical analysis. The mean and standard errors of the data were computed. The data were subjected to analysis of variance, ANOVA (Sokal and Rohil, 1973), followed by Duncan's multiple range test, DMRT (Duncan, $1955)$, at $5 \%$ and $1 \%$ levels.

\section{RESULTS}

\section{Series I}

When exposed to LL and LDL during the early reproductive phase (first week of May) stimulated males regressed in $\mathrm{LL}$ $(P<0.001)$, but not in LDL within $30 \mathrm{~d}$; in fact, LDL birds maintained enlarged testes until d 30 (fig 1A). The females responded in a similar manner but no significant regression was found in ovarian follicles of LL birds on d 30 (fig 1B). How- ever, fully regressed gonads $(P<0.001$, ANOVA; $P<0.01$, DMRT) were found in all birds in both treatment-groups by $d 60$ (fig 1); the birds remained gonadally regressed until the end of the experiment. In $\mathrm{NDL}$, the birds had active gonads until $d$ 60 (early July) after which they underwent regression. Fully regressed $(P<0.001$, ANOVA) testes and ovaries were found in NDL birds on d 120, in early September (fig 1A, B).

The data from the second experiment (fig 2) reveal that transfer to LDL at the time when the gonads had begun to regress had no effect on the rate of gonadal

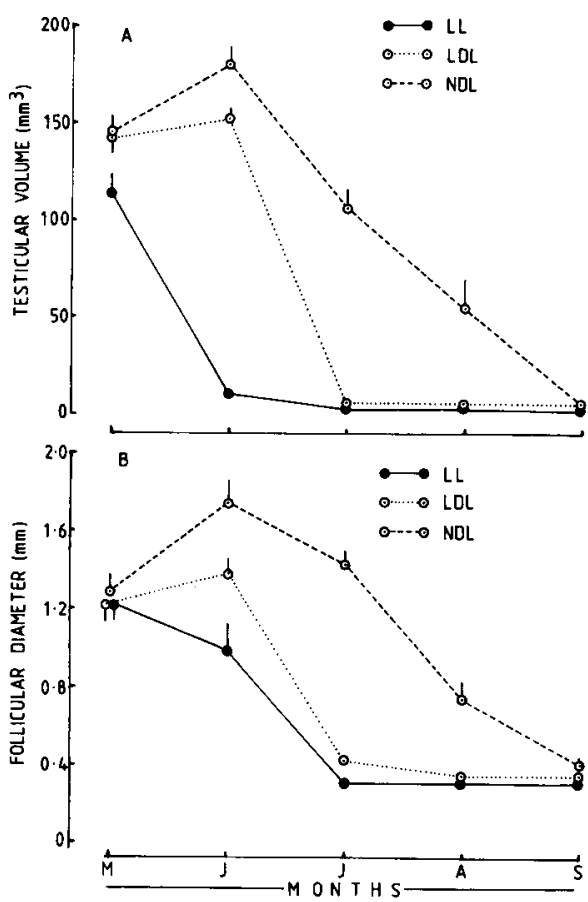

Fig 1. Gonadal response in brahminy myna transferred from NDL to continuous light (LL) and long daily photoperiods, LDL (16:8 D) in the first week of May and maintained for 4 months on this schedule. Each circle represents the mean for data on a group of birds; the vertical bar indicates limits of the standard error. 


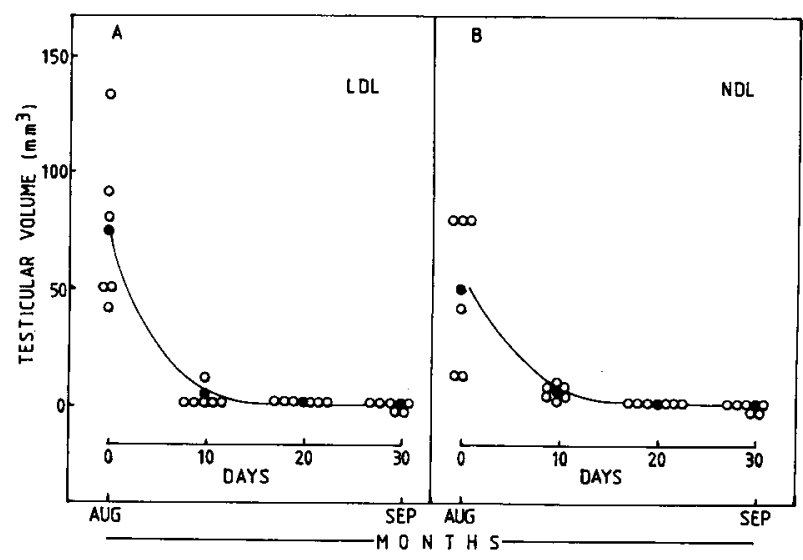

Fig 2. The changes in testicular volume at 10-d-intervals in groups of brahminy myna kept in LDL, 16 $L: 8 D(A)$ and NDL (B) for $30 \mathrm{~d}$ from the first week of August. Open circles represents individual data; solid circles indicate the mean for the group. Gonadal regression trend is shown by a curved line which eventually becomes horizontal between the last 3 mean points.

regression (cf figs $1 A, 2 A$ ). Fully regressed testes were found in LDL birds by d 10 (fig 2A). The following observations (d 20 and 30) revealed fully involuted testes in NDL as well as in LDL groups.

\section{Series II}

The results from this series (fig 3 ) confirm that the change in daylength had no effect on the reproductive cycle of brahminy myna at the onset of gonadal regression. The gonads collapse $(P<0.001$, ANOVA; $P<0.01$, DMRT) within $30 \mathrm{~d}$ of exposure to $12 \mathrm{~L}, 14 \mathrm{~L}, 16 \mathrm{~L}$ and $\mathrm{LL}$. These birds remained gonadally regressed until the end of the experiment. A transfer of $12 \mathrm{~L}, 14 \mathrm{~L}$ and $16 \mathrm{~L}$ birds to $24 \mathrm{~h}$ light caused no renewed gonadal growth, indicating that the birds had become absolutely photorefractory.

\section{Series III}

The results are summarized in figure 4 . As expected, short days caused complete gonadal regression $(P<0.001$, ANOVA; $P<0.01$, DMRT) at the time when birds experiencing natural daylengths had enlarged gonads (fig 4). Gonads of the shortday group of birds did not recrudesce on subsequent transfer for $60 \mathrm{~d}$ to $12 \mathrm{~L}$ or 14 $L$ (fig $4 A$ ), except for a slight initiation in a few females in the $12 \mathrm{~L}$ (fig 4B). The transfer of these birds to $L L$ for $30 \mathrm{~d}$ also failed to cause gonadal growth (fig 4). On the other hand, the testes of a few birds in the group were slightly stimulated in $16 \mathrm{~L}$ and LL, although the average TV for the group was never statistically different (fig 4A). However, the females in these treatment groups exhibited ovarian development ( $P<0.01$, DMRT; fig 4B). These partially stimulated birds became fully regressed after the next $30 \mathrm{~d}$ (fig 4). 


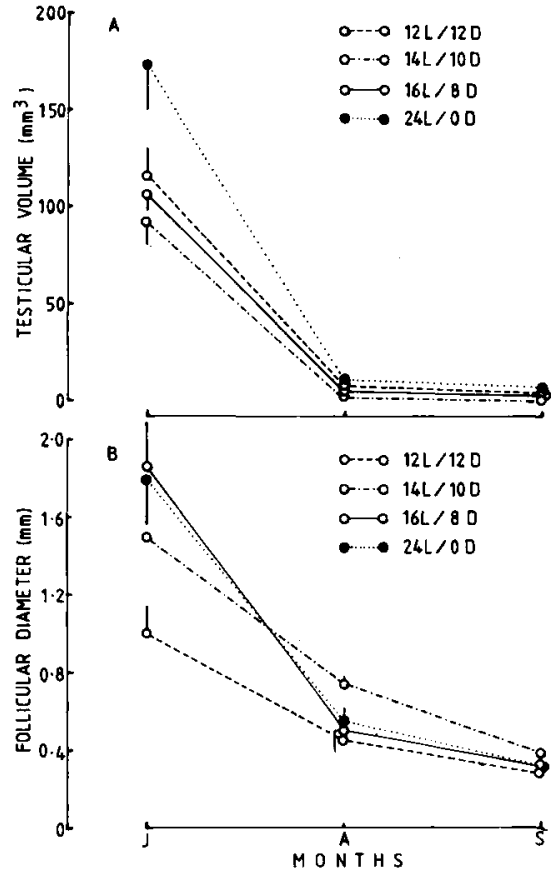

Flg 3. Gonadal regression in brahminy myna exposed for $60 \mathrm{~d}$ to different photoperiods (12 L, $14 \mathrm{~L}, 16 \mathrm{~L}$ and $\mathrm{LL}$ ) from 23rd of July. The birds were examined at 30-d intervals. The first measurement was made 1 day prior to experimentation. A higher $24 \mathrm{~L}$ group in males and lower 12 $L$ group in females was found incidentally due to random grouping and the inclusion of a few birds with large or small gonads. Note that this was the time of onset of gonadal regression. Circles and vertical bars represent mean data and standard error respectively for a group of birds. Note that $12 \mathrm{~L}, 14 \mathrm{~L}$ and $16 \mathrm{~L}$ groups were transferred to $L L$ on $d 30$.

\section{DISCUSSION}

Results of the present study (figs 1-4) confirm that in brahminy myna the breeding season is terminated by a state of photorefractoriness which develops after attainment of full gonadal maturation. The data from the series I experiments provide evidence that the timing of the onset of re-

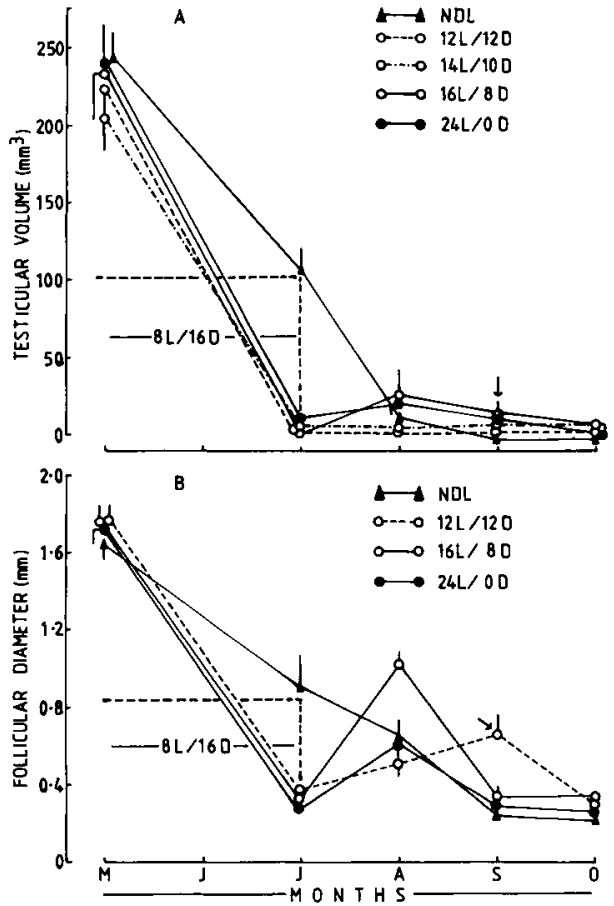

Fig 4. Photoresponse of male (A) and female (B) brahminy myna subjected to short days (8 L:16 D) for $60 \mathrm{~d}$ from the third week of May and subsequently transferred to different photoperiods ( $12 \mathrm{~L}, 14 \mathrm{~L}, 16 \mathrm{~L}$ and $24 \mathrm{~L}$ ) for $90 \mathrm{~d}$. Small arrows $(\downarrow)$ pointing towards September data indicate the transfer of $12 \mathrm{~L}$ and $14 \mathrm{~L}$ groups to LL. Each circle represents mean data for the groups examined and vertical bars denote standard error. The data for an NDL group of birds are is represented by solid triangles and indicate the gonadal regression trend in nature.

fractoriness can be modified by exposure to longer daylengths; birds in LDL regressed later than those in LL, but earlier than NDL birds (fig 1). Also, as in other photoperiodic species exhibiting refractoriness (Wolfson, 1959; Storey and Nicholls, 1976; Harris and Turek, 1982; Dawson and Goldsmith, 1983), the time taken to undergo spontaneous gonadal regression 
in brahminy myna appeared to be an inverse function of the duration of the daylength experienced, once the period of minimum daily photoperiod inducing refractoriness was exceeded. In other words, the development of refractoriness was hastened by exposure to long photoperiods; the longer the photoperiods, the sooner the birds became photorefractory. However, this was true when the birds were exposed to long daylengths at the time of full gonadal maturation (cf figs $1 \mathrm{~A}$ and 2 ). The data in experiment II (fig 2) indicate that exposure to LDL at the onset of gonadal regression had no effect whatever on the rate of gonadal regression.

Experiments in series II confirm that the loss of response to photoperiods during the late reproductive period was absolute, since exposure to any stimulatory photoperiods in late July did not extend the breeding season in this species. This is inconsistent with the findings on some photoperiodic birds and mammals (house sparrow: Vaugien, 1955; duck: Assenmacher and Tixier-Vidal, 1962; house finch: Hamner, 1968; quail: Robinson and Follett, 1982; ewe: Malpaux et al, 1988), showing that the natural breeding season can be prolonged by providing further photoperiodic stimulation shortly before regression or anestrus sets in.

Since exposure of gonadally-regressed birds to $24 \mathrm{~h}$ light caused no renewed growth (figs 1, 3 and 4), this species becomes, by definition, totally photorefractory. The refractoriness that developed in the brahminy myna thus resembles that described in white-crowned sparrows (Sansum and King, 1976), starlings (Bissonnette and Wadlund, 1932; Dawson et al, 1985, 1986; Nicholls et al, 1987), willow ptarmigan (Stokkan and Sharp, 1984) and Svalbard ptarmigan (Stokkan et al, 1986). It is also comparable to the loss of response under long photoperiods (15 $\mathrm{L}$ or
LL) observed in a fow palaeoarctic-Indian migrants overwintering in India (Emberiza melanocephala; Tewary and Kumar, 1982; Kumar and Tewary, 1983; $E$ bruniceps: Prasad and Tewary, 1982; Tewary and Tripathi, 1983); however, the issue of absolute or relative refractory period has not been examined in these species.

Series III provides evidence for the involvement of the photoperiod in the development of photorefractoriness. It is known that short daylengths are used to terminate photorefractoriness and ensure photosensitivity in long daylength breeding species. In a separate study, we have observed that the gonads of brahminy myna exposed to $8 \mathrm{~L}$ or $9 \mathrm{~L}$ for 2-4 months from February/March were stimulated within $3 \mathrm{~d}$ of transfer to LDL, and that this treatment ensured photosensitivity in the postreproductive regressed individuals (unpublished observations). In the present study, birds exposed to $8 \mathrm{~L}$ since the third wk of May failed to respond when subjected to $12 \mathrm{~L}$ or $14 \mathrm{~L}$ for $60 \mathrm{~d}$ and subsequently to $\mathrm{LL}$ for $30 \mathrm{~d}$. Although a short subsequent gonadal cycle, like that in golden-crowned sparrows (Turek, 1975), was induced in females of $16 \mathrm{~L}$ and $\mathrm{LL}$ groups, only 1 or 2 birds of the $16 \mathrm{~L}$ and $\mathrm{LL}$ male groups showed slightly initiated testes. The difference between the 2 sexes in this experiment in response to photostimulation could be attributed to the reproductive status of the birds at the time when they were shifted to $8 \mathrm{~L}$. Since the ovary matures after the testis, it is possible that the females were not fully reproductively mature when transferred to $8 \mathrm{~L}$. Further, it is not possible to ascertain at present whether partial response in a few birds in some groups was because $8 \mathrm{~L}$ prevented the development of full photorefractoriness, or whether, having become photorefractory, the birds were then rendered partially photosensitive again as a result of $8 \mathrm{~L}$ treatment. 
An interesting observation is that LDL maintained gonadal growth (at least for 30 d) in birds which were exposed to LDL in early May (fig 1), but not in late July (fig 3) or early August (fig 2 ). In addition, $8 \mathrm{~L}$ rendered full photosensitivity in February/ March, but not in late May (fig 4). This suggests that birds will not enter a photorefractory state unless they have attained full gonadal maturation, and that the development of photorefractoriness becomes inevitable before gonadal regression. This raises the possibility that in brahminy myna in nature, spring/summer daylengths not only induce gonadal development, but also program for spontaneous gonadal regression in late summer. Whether photorefractoriness is fixed by daylengths experienced before the gonads have attained maximal growth (Moore et al, 1983), or whether it is fixed by the daylength available at the end of gonadal growth as in starlings (Falk and Gwinner, 1988), has to be further investigated. However, these observations indicate that brahminy myna has its own endogenous program for a gonadal growth-involution cycle which can be modified by environmental photoperiods. While longer photoperiods hasten gonadal growth and onset of refractoriness during early gonadal growth phase, the breeding season is not prolonged once the gonads have matured.

Our findings are not in agreement with those on the responses of some other tropical photoperiodic species. For instance, in low-latitude Ploceus philippinus (Thapliyal and Saxena, 1964; Singh and Chandola, 1981) and Zonotrichia capensis (Miller, 1965; Epple et al, 1972; Lewis et al, 1974) the transition from breeding to regression is not associated with loss of response to the inductive ( $\geq 15 \mathrm{~h}$ ) daily photoperiods, which under laboratory conditions induce gonadal development during sexually quiescent periods and keep the gonads active for a long time or indefinitely. However, a seasonal decline in photosensitivity to LDL and loss of response to only natural daylengths have been suggested in $P$ philippinus at $25^{\circ} \mathrm{N}$ (Singh and Chandola, 1982; Chakravorty and Chandola-Saklani, 1985). Not withstanding, spontaneous gonadal regression under LDL has been observed in tropical Acrilotheres tristis (Thapliyal, 1981) and Gymnorhis xanthocollis (Tewary and Tripathi, 1985; Tewary and Dixit, 1986), but it is not known if the regressed individuals respond on subsequent transfer to longer photoperiods or LL. Further, a brief photorefractory period observed in low-atitude Quelea does not resemble the temperate type of photorefractoriness, for it is dissipated spontaneously irrespective of the photoperiods (Lofts, 1962). The present findings therefore establish that the termination of the breeding season by absolute photorefractoriness also occurs in birds breeding in the tropics.

\section{ACKNOWLEDGMENTS}

Financial assistance from the Department of Science and Technology is gratefully acknowledged. We thank both anonymous reviewers for critical comments and constructive suggestions.

\section{REFERENCES}

Ali S, Ripley SD (1972) Handbook of Birds in India and Pakistan. Oxford University Press, Delhi, vol 5, 160-162

Assenmacher I, Tixier-Vidal A (1962) La réactivité à divers agents de l'axe hypophysetesticule du canard traité à l'extrême début de la "période réfractaire" du cycle sexuel. CR Seances Soc Biol (Paris) 156, 267-272

Bissonnette TH, Wadlund AP (1932) Duration of testis activity of Sturnus vulgaris in relation to type of illumination. J Exp Bio/ 9, 339-350 
Chakravorty K, Chandola-Saklani A (1985) Termination of seasonal breeding in a weaver finch, Ploceus philippinus: role of photoperiod. J Exp Zool 235, 381-386

Chandola A, Saklani M, Bisht M, Bhatt D (1983) Reproduction strategies in birds of the tropics. In: Adaptations to Terrestrial Environments (Margaris NS, Arianoustou-Faraggitaki $M$, Reiter RJ, eds) Plenum Publishing Corp, 145-164

Dawson A (1987) Photorefractoriness in European starlings: critical daylength is not affected by photoperiodic history. Physiot Zool 60, 722-729

Dawson A, Goldsmith AR (1983) Plasma prolactin and gonadotropin during gonadal development and the onset of photorefractoriness in male and female starlings (Sturnus vulgaris) on artificial photoperiods. J Endocrinol 97, 253-260

Dawson A, Goldsmith AR, Nicholls TJ (1985) Development of photorefractoriness in intact and castrated male starlings (Sturnus vulgaris) exposed to different periods of long daylengths. Physiol Zool 53, 253-261

Dawson A, Goldsmith AR, Nicholls TJ, Follett BK (1986) Endocrine changes associated with the termination of photorefractoriness by short daylengths and thyroidectomy in starlings (Sturnus vulgaris). J Endocrinol 110, 73-79

Dittami JP, Gwinner E (1985) Annual cycles in the African stonechat Saxicola torquata axillaris and their relationship to environmental factors. J Zool (Lond) (A) 207, 357-370

Duncan DB (1955) Multiple range and multiple $F$ tests. Biometrics 11, 1-42

Epple A, Orians GH, Farner DS, Lewis RA (1972) The photoperiodic testicular response of a tropical finch, Zonotrichia capensis coastaricensis. Condor 74, 1-4

Falk H, Gwinner E (1988) Timing of photorefractoriness in the European starling: significance of photoperiod early and late in the reproductive cycle. Biol Reprod 39, 1004-1008

Farner DS, Lewis RA (1971) Photoperiodism and reproductive cycles in birds. In: Photophysiology (Farner DS, Lewis RA, eds) Academic Press, NY, 325-370

Farner DS, Donham RS, Matt KS, Moore MC, Wingfield JC (1983) The nature of photore- fractoriness. In: Avian Endocrinology: Environmental and Ecological Perspectives (Mikami S, Homma K, Wada M, eds) JSSP Tokyo/Springer-Verlag, Berlin, 145-166

Follett BK (1984) Birds. In: Marshall's Physiology of Reproduction (Lamming GE, ed) Churchill Livingstone, Edinburgh, 283-350

Gwinner E, Dittami JP (1985) Photoperiodic responses in temperate zone and equatorial stonechats: a contribution to the problem of photoperiodism in tropical organisms. In: The Endocrine System and the Environment (Ishii $S$, Follett BK, Chandola A, eds) SpringerVerlag, Berlin, 279-294

Hamner WM (1968) The photorefractory period of the house-finch. Ecology 49, 211-227

Harris MO, Turek FW (1982) Photoperiodic control of the timing of testicular regression in white-throated sparrows. Gen Comp Endocrinol 46, 124-129

Kumar BS (1988) Photoperiodism in brahminy myna, Sturnus pagodarum (Gmelin); M Phil Dissertation, Meerut Univ Meerut

Kumar V, Tewary PD (1983) Response to experimental photoperiods by a migratory bunting, Emberiza melanocephala. Ibis 125, 305-312

Lewis RA, King JR, Farner DS (1974) Photoperiodic responses of a subtropical population of a finch (Zonotrichia capensis hypoleuca). Condor 76, 233-237

Lofts B (1962) Photoperiod and refractory period of reproduction in an equatorial bird Quelea quelea. Ibis 104, 407-414

Lofts B (1975) Environmental control of reproduction. Symp Zool Soc (Lond) 35, 177-197

Lofts B, Murton RK (1973) Reproduction in birds. In: Avian Biology (Farner DS, King JR, eds) Academic Press NY, vol 3, 1-107

Lofts B, Murton RK, Thearle RJP (1973) The effects of testosterone propionate and gonadotropins on the bill pigmentation and testes of the house-sparrow Passer domesticus. Gen Comp Endocrinol 21, 202-209

Malpaux B, Robinson JE, Brown MB, Karsch FJ (1988) Importance of changing photoperiod and melatonin secretory pattern in determining the length of the breeding season in the Suffolk ewe. J Reprod Fertil 83, 461-470

Miller AH (1965) Capacity for photoperiodic response and endogenous factors in the repro- 
ductive cycles of an equatorial sparrow. Proc Int Congr Zoll (Wash) 166

Moore MC, Schwab H, Farner DS (1983) Biochronometry of testicular regression in whitecrowned sparrows (Zonotrichia leucophrys gambelii). J Comp Physiol 153, 489-494

Murton RK, Westwood NJ (1977) Avian Breeding Cycles. Clarendon Press, Oxford

Nicholls TJ, Goldsmith AR, Follett BK, Dawson A (1987) The photoperiodic responses of European starlings (Sturnus vulgaris). In: Comparative Physiology of Environmental Adaptations (Pevet P, ed) Karger, Basel, vol 3, 23-29

Nicholls TJ, Goldsmith AR, Dawson A (1988) Photorefractoriness in birds and comparison with mammals. Physiol Rev 68, 133-176

Prasad BN, Tewary PD (1982) Photoperiodic response and photorefractoriness in a subtropical migratory finch, redheaded bunting, $\mathrm{Em}$ beriza bruniceps. Ind $J$ Zool 10, 15-19

Robinson JE, Follett BK (1982) Photoperiodism in Japanese quail: the termination of seasonal breeding by photorefractoriness. Proc $R$ Soc (Lond) B 215, 95-116

Sansum EL, King JR (1976) Long-term effects of constant photoperiods on testicular cycles of white-crowned sparrows (Zonotrichia leucophrys gameblii). Physiol Zool 49, 407-416

Singh S, Chandola A (1981) Photoperiodic control of seasonal reproduction in tropical weaver bird. J Exp Zool 216, 293-298

Singh S, Chandola A (1982) Seasonal variation in photogonadal response of tropical weaver bird. Gen Comp Endocrinol 45, 521-526

Sokal PR, Rohlf FJ (1973) Introduction to Biostatistics. WH Freeman and Co, San Francisco

Stokkan KA, Sharp PJ (1984) The development of photorefractoriness in castrated willow ptarmigan (Lagopus lagopus lagopus). Gen Comp Endocrinol 54, 402-408

Stokkan KA, Sharp PJ, Unander S (1986) The annual breeding cycle of the high-arctic Svalbard ptarmigan (Lagopus mutus hyperboreus). Gen Comp Endocrinol 61, 446-451
Storey CR, Nicholls TJ (1976) Some effects of manipulation of daily photoperiod on the rate of onset of a photorefractory state in canaries (Serinus canarius). Gen Comp Endocrinol 30, 204-208

Tewary PD, Dixit AS (1986) Photoperiodic regulation of the reproduction in subtropical female yellow-throated sparrows (Gymnorhis xanthocollis). Condor 88, 70-73

Tewary PD, Kumar V (1982) Photoperiodic responses of a subtropical migratory finch, the blackheaded bunting, Emberiza melanocephala. Condor 84, 168-171

Tewary PD, Tripathi BK (1983) Photoperiodic control of reproduction in female redheaded bunting. $J$ Exp Zoo/ 226, 269-272

Tewary PD, Tripathi PM (1985) Photoperiodic induction of testicular growth in the subtropical yellow-throated sparrows. Gymnorhis xanthocollis. Arch Bio/ 96, 425-439

Thapliyal JP (1981) Endocrinology of avian reproduction. Presidential address, Ind Sci Congr Assoc January, 1981, Varanasi, India, 1-30

Thapliyal JP, Saxena RN (1964) Absence of refractory period in common weaver bird. Condor 66, 199-208

Thapliyal JP, Tewary PD (1964) Effect of light on the pituitary, gonad and plumage pigmentation in the avadevat, Estrilda amandava and baya weaver, Ploceus philippinus. Proc Zool Soc (Lond) 142, 67-71

Turek FW (1975) The termination of the avian photorefractory period and the subsequent gonadal response. Gen Comp Endocrinol 26, 562-564

Vaugien $L$ (1955) Sur les réactions testiculaires du jeune moineau domestique à l'illumination de diverses époques de la mauvaise saison. Bull Biol Fr Belg 89, 218-244

Wolfson A (1959) The role of light and darkness in the regulation of spring migration and reproductive cycles in birds. In: Photoperiodism and Related Phenomena in Plants and Animals (Withrow RB, ed) Am Assoc Advancement of Science, Washington, 679-716 